\title{
The history and legacy of reintroduction of beavers in the European North of Russia
}

\author{
Pjotr I. Danilov \& Fyodor V. Fyodorov
}

\begin{abstract}
In the European North of Russia the Eurasian beaver had been extirpated over two hundred years ago. Owing to active introduction and dispersals from the 1930s to the 1950s, beavers have recolonized the natural ecosystems in the European North. Furthermore, Finland and Russia (Karelia, Leningrad and Arkhangelsk provinces) are now co-inhabited by two beaver species - the North American (Castor canadensis Kuhl) and the Eurasian (C. fiber L.) beaver. North American beavers, which have colonized a major part of Finland, Karelia and the Karelian Isthmus in the Leningrad Province, descended from the seven animals brought to Finland from the USA in the 1930s (Linnamies, 1956; Siivonen, 1956; Lahti, 1968). Subsequent intraregional translocations of these animals took place in both Finland and Russia ( $n=270)$. The main origins of Eurasian beavers introduced in provinces adjacent to Karelia (Arkhangelsk, Vologda and Leningrad provinces) $(n=1349)$ were the Voronezh Province $(26.5 \%$ of all releases in the study area), Republic of Belarus (20.8\%), Mari El Republic (12.5\%), Smolensk Province (6.2\%), Bryansk Province (5.3\%), Ryazan Province (3.6\%), Komi Republic (1.5\%), and other regions $(5.6 \%)$. Intraregional translocations of the Eurasian beaver were also conducted (18\%). In total, more than 1800 Eurasian beavers were introduced in the European North of Russia (Murmansk, Leningrad, Novgorod, Pskov, Arkhangelsk and Vologda provinces). The present-day North American beaver population is estimated at 12000 animals in Karelia and 1000 in the Karelian Isthmus, Leningrad Province (Danilov et al., 2007, 2012). Eurasian beaver numbers are estimated at 4000 animals in Karelia (Danilov \& Fyodorov, unpublished data), with fewer than 40 beavers in the Murmansk Province (Kataev, 2015), 23000 in the Leningrad Province, 25000 in the Novgorod Province, 17600 in the Pskov Province, 21000 in the Arkhangelsk Province, and 32600 animals in the Vologda Province (Borisov, 2011). Presently, Eurasian beavers live in those areas in southern Karelia that were inhabited by North American beavers since they were released there at the end of the 1960s, i.e. one species has been replaced by the other (Danilov et al., 2007, 2011; Danilov \& Fyodorov, 2015a). In southern Karelia, the closest distance between colonies of different beaver species is $10 \mathrm{~km}$. Conversely, in north-eastern Karelia (Kemsky District), North American beavers penetrated into the Arkhangelsk Province and are colonizing areas inhabited by the Eurasian beaver. In 2015, they were spotted in the Arkhangelsk Province, $70 \mathrm{~km}$ east of the administrative border with Karelia.
\end{abstract}

KEY WORDS: North American and Eurasian beavers, natural dispersal, introduction.

Pjotr I. Danilov [pjotr.danilov@mail.ru], Institute of Biology Karelian Research Centre of RAS, Pushkinskaya 11, Petrozavodsk 185910, Russia; Fyodor V. Fyodorov [ffyodor@krc.karelia.ru], Institute of Biology Karelian Research Centre of RAS, Pushkinskaya 11, Petrozavodsk 185910, Russia.

\section{История и результаты возвращения речных бобров на Европейском Севере России}

\section{П.И. Данилов, Ф.В. Фёдоров}

РЕЗЮМЕ. На Европейском Севере России бобр был истреблен более двухсот лет назад. Благодаря активному расселению животных в 1930-1950 гг. бобра удалось вернуть в природные комплексы Европейского Севера. Более того, в настоящее время в Финляндии и России (Карелия, Ленинградская и Архангельская обл.) обитают два вида - североамериканский (Castor canadensis Kuhl) и евразийский (C. fiber L.) бобры. Популяция североамериканских бобров, заселившая большую часть Финляндии, Карелии и Карельский перешеек Ленинградской обл., происходит от 7 зверей, привезённых в Финляндию из США ещё в 1930-е гг. (Linnamies, 1956; Siivonen, 1956; Lahti, 1968). Впоследствии и в Финляндии, и в России проводили внутрирегиональные выпуски $(n=270)$. Основными источниками племенного материала C.fiber в соседних с Карелией областях (Архангельская, Вологодская и Ленинградская) $(n=1349)$ стали Воронежская область $(26,5 \%$ всех выпусков в регионе), Белоруссия (20,8\%) и Марийская АССР (12,5\%), а также Смоленская $(6,2 \%)$, Брянская $(5,3 \%)$ и Рязанская $(3,6 \%)$ области, Коми АССР $(1,5 \%)$ и др. регионы $(5,6 \%)$. Осуществляли и внутриобластное расселение бобров этого вида (18\%). Всего на Европейском Севере России (Мурманская, 
Ленинградская, Новгородская, Псковская, Архангельская и Вологодская области) было выпущено более 1800 евразийских бобров. Современная численность североамериканских бобров составляет 12000 зверей в Карелии и 1000 - на Карельском перешейке Ленинградской обл. Численность евразийских бобров в Карелии оценивается в 4000 особей (наши данные), в Мурманской обл. менее 40 (Катаев, 2015), Ленинградской - 23000, Новгородской - 25000, Псковской - 17600, Архангельской — 21000 и в Вологодской обл. - 32600 зверей (Борисов, 2011). Сейчас на юге Карелии евразийские бобры заселили территорию, где прежде (с конца 1960-х гг.) обитали бобры североамериканские, т.е. произошло замещение одного вида другим. Ближайшее расстояние между поселениями бобров, принадлежащих к разным видам, составляет 10 км. С северо-востока Карелии североамериканские бобры приникли в Архангельскую область в пределы обитания евразийских бобров. В 2015 г. они были зарегистрированы уже в 70 км восточнее границы с Карелией.

КЛЮЧЕВЫЕ СЛОВА: североамериканский и евразийский бобры, интродукция, естественное расселение.

\section{Introduction}

Beavers once were a common species in Europe. Evidence of their previous abundance is the numerous beaver remains found in Neolithic cemeteries and among food residues in excavated Neolithic sites, beaver images among petroglyphs, records in the national epic literature, place names that take root from the word "beaver", and fur trade history. However, at the end of the $19^{\text {th }}$ century, beavers were on the verge of extinction due to over hunting. Only through extensive work of restoring the species within its former range, the beaver has re-colonized the natural ecosystems. Owing to a number of reasons, some regions of the European North of Russia (Karelia, the Karelian Isthmus in the Leningrad Province, north-west of the Arkhangelsk Province) are now co-inhabited by two beaver species - the North American (Castor canadensis Kuhl) and the Eurasian (C. fiber L.) beaver.

Monitoring of dispersal and distribution of Eurasian and North American beavers once again convinces us that co-habitation of ecologically similar species inevitably leads to interspecific competition and results in the displacement of one species by another. Initially, we suggested that the North American beaver might displace the Eurasian beaver. This suggestion came from an analysis of the numbers and population dynamics of these species in Finland (Lahti \& Helminen, 1980; Ermala et al., 1989, etc.). According to Finnish researchers, dissemination and population growth of North American beavers have caused the decrease in number of Eurasian beavers and made it impossible for them to expand their habitat in the southwest of Finland.

To confirm this hypothesis, we monitored the areas where presumably two species live close to each other and species identification was conducted. As a result, a few years later we determined that in southern Karelia, many areas where North American beavers have been released and where their colonies had established successfully, were now occupied by Eurasian beavers. This situation led us to conclude that the replacement of the North American beaver by the Eurasian beaver took place in southern Karelia. Similar data were collected in the central and northern regions of Karelia, where North American beavers have appeared as a result of natural and human-aided dispersal.

This paper discusses the history of beaver dispersal in the European North of Russia and provides more precise estimates of the numbers and distribution of both Eurasian and North American beavers in the region.

\section{Materials and methods}

The paper is based on the analysis of literature and archival data, our own long-term observations of the dispersal, population dynamics, and distribution of Eurasian and North American beavers as well as on studies of the peculiarities of their ecology in the European North of Russia. The study involved more than 800 colonies of both beaver species. We used both traditional and original methods of data collection, including regular questionnaires, and an analysis of archival records and documents from the Russian Research Institute of Game Management and Fur Farming (Western Branch) and regional Game Departments.

\section{Results}

Far in the past, the beaver used to be a common game species in Northern Europe. We know this from the preserved Neolithic monuments - petroglyphs of the Lake Onega and White Sea areas, as well as from excavated archaeological findings. The great significance of beaver in the life of the people inhabiting the area and its wide distribution in the past is indirectly evidenced by the place names that take root from the word "beaver".

In the $17^{\text {th }}$ century, beaver hunting in many parts of the European North of Russia experienced a heavy decline, and in the late $19^{\text {th }}$ century the beaver essentially ceased to exist as game animal throughout the European North of Russia.

Restoration of beaver populations in the European North of Russia began in the 1930s with the introduc- 


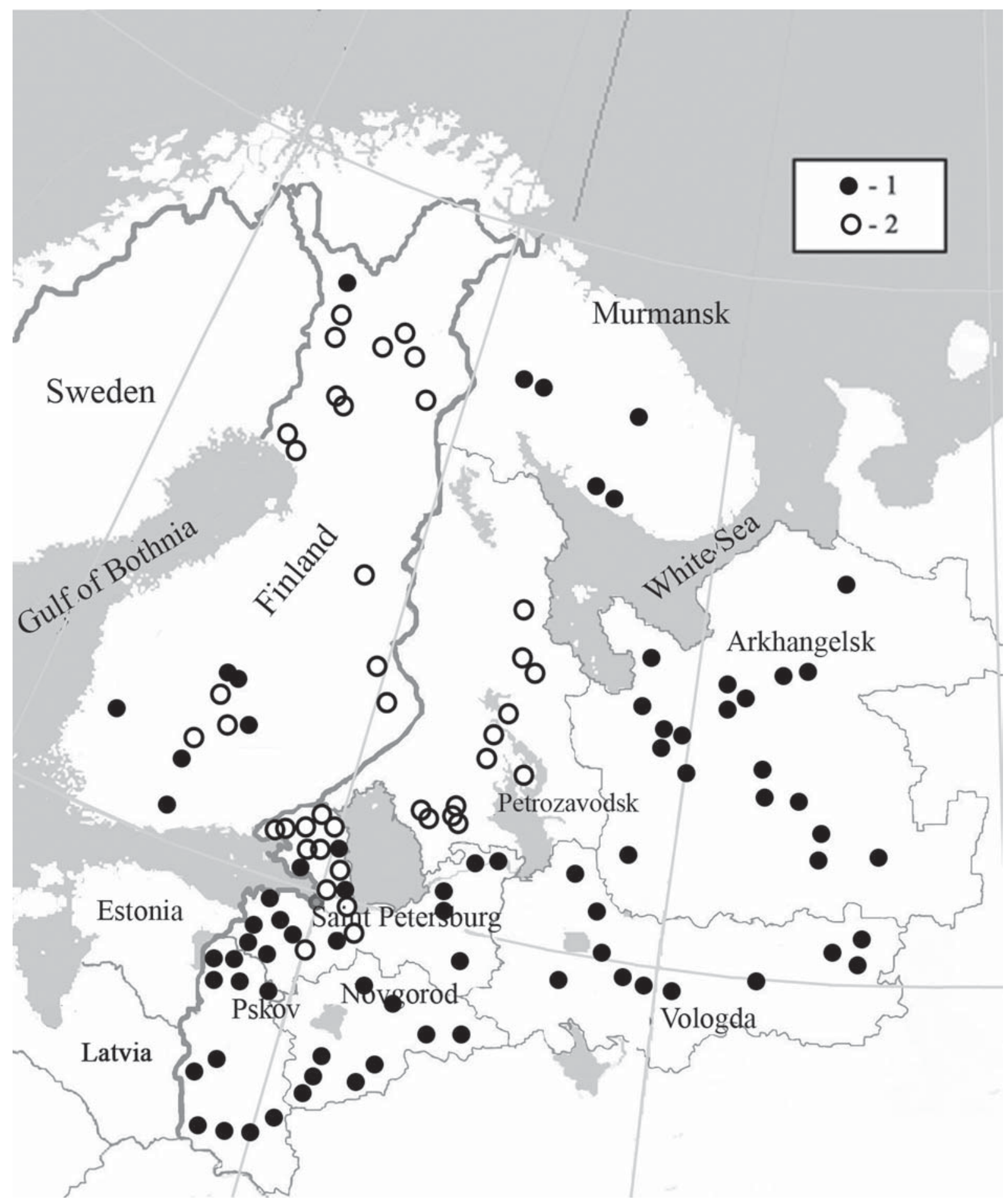

Fig. 1. Release sites of Eurasian (1) and North American (2) beavers in the Russian European North and Finland (after: Semyonov-Tyan-Shansky, 1938; Linnamies, 1956; Siivonen, 1956; Lahti, 1968; Ermala et al., 1989; Danilov \& Fyodorov, 2007; Danilov, 2009).

tion of beavers on the Kola Peninsula (SemyonovTyan-Shansky, 1938). Thereafter, beavers were released in all areas of the European North of Russia, except for Karelia. More than 1800 beavers were released in the region (Fig. 1) (Provorov, 1963, 1969; Safonov \& Pavlov, 1973; Ivanov, 1975; Danilov et al., 2007). Through natural dispersal, beavers also appeared in Karelia. 
The present-day Eurasian beaver population in Karelia is more than 4000 individuals (Danilov \& Fyodorov, 2015a). In other regions, experts estimate Eurasian beaver numbers to be fewer than 40 beavers in the Murmansk Province (Kataev, 2015), 23000 in the Leningrad Province, 25000 in the Novgorod Province, 17600 in the Pskov Province, 21000 in the Arkhangelsk Province, and 32600 animals in the Vologda Province (Borisov, 2011).

North American beavers first appeared in Russia early in the 1950 s, and nearly simultaneously in southern and western Karelia and the Karelian Isthmus of the Leningrad Province (Zaikin, 1959; Segal \& Orlova, 1961; Danilov, 1972, 1975; Ivanov, 1975) through dispersal from Finland, where the animals had been released in the mid-1930s (Fig. 1) (Linnamies, 1956; Lahti \& Helminen, 1969). Later on, intraregional translocations of these animals took place in both Karelia and Karelian Isthmus $(n=270)$ (Danilov et al., 2007, 2011).

Relatively quickly, beavers moved to the south and east of Karelia and to the Karelian Isthmus. Eventually, in the early 1990s, they reached the easternmost districts of Karelia - Belomorsk and Segezha, and then expanded to the Arkhangelsk Province (Fig. 2).

The number of North American beavers in the 2000s is estimated at 12000 individuals in Karelia and 1000 individuals on the Karelian Isthmus of the Leningrad Province (Danilov et al., 2007). A present-day estimate is more than 15000 individuals (Danilov \& Fyodorov, 2015a).

\section{Discussion}

Until the 2000s, studies of beaver dispersal in the European North of Russia, and changes in their abundance and distribution, were sporadic. In the late 1990s in Karelia, this lack of data made it difficult to explain why there began to be reports of Eurasian beavers being harvested in the area where North American beavers had been released and had flourished for many years.

The need for special studies to identify species distribution ranges was evident, and in the early 2000s, we started to collect data on species identification of animals in Karelia in the area presumably co-inhabited by both species. Currently in area of almost $160 \mathrm{~km}$ long and 50 to $70 \mathrm{~km}$ wide in southern Karelia, the North American beaver is being replaced by the Eurasian beaver (Danilov et al., 2007, 2011). The southern boundary of the North American beaver range, for 20 years in some places, retreated by $50 \mathrm{~km}$ to the north. In a number of places, the two species co-exist on the tributaries of one river, and the shortest distance between their colonies is less than $10 \mathrm{~km}$ (Fig. 2).

It is impossible to confirm what is happening in the north-eastern limit of the North American beaver distribution in Russia. North American beavers penetrated to the Arkhangelsk Province in the early 2000s and rather quickly dispersed to habitats occupied by Eurasian bea-

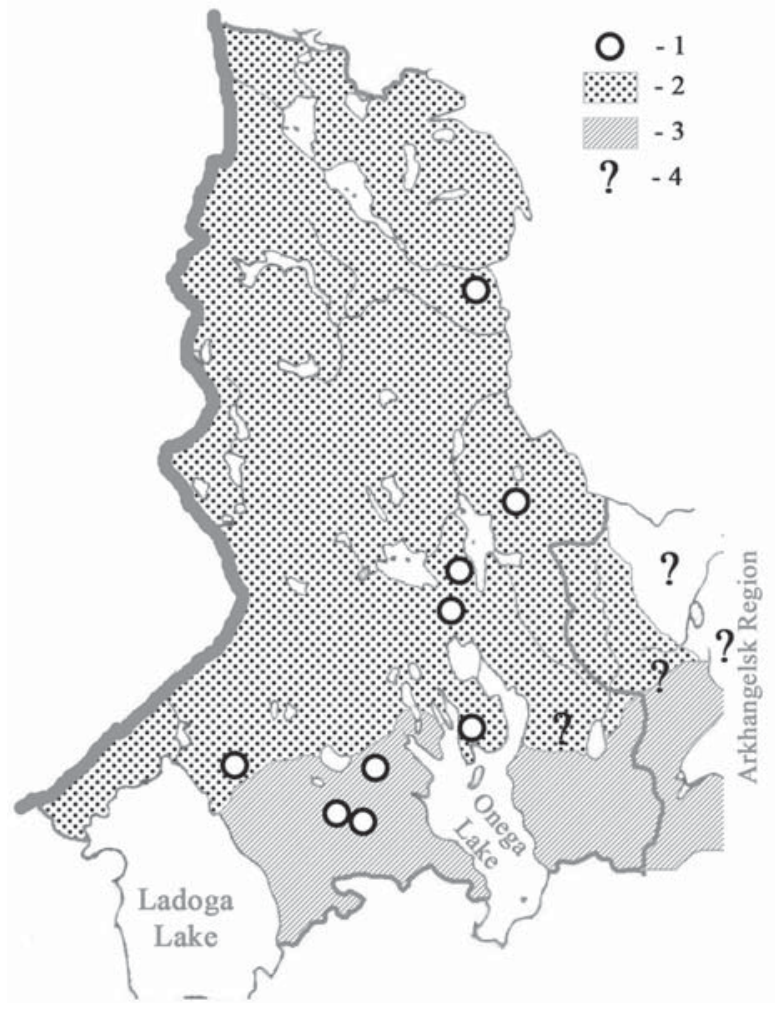

Fig. 2. Present-day distribution of beavers in Karelia and partly in Arkhangelsk Province: 1 - the release sites of $C$. canadensis, 2 - territory occupied by $C$. canadensis, 3 territory occupied by $C$. fiber, 4 - no information.

vers. In 2015, we found that the North American beaver is present in the Arkhangelsk Province as far as $70 \mathrm{~km}$ east of the administrative border of Karelia (Fig. 2).

To understand these phenomena, we need to conduct a detailed study of biology (including behavior) of individuals from both species that are living on the same territory under the same environmental conditions, as well as an analysis of the genetic diversity of their populations, etc. A possible answer to the question «who will win» perhaps lies in the origin of beavers in the European North of Russia. In our work, we have focused on the analysis of the origin of the animals that have become a source for the colonies in places where they are currently.

The population of North American beavers that have colonized a major part of Finland, Karelia and part of the Leningrad Province, descended from the seven animals brought to Finland from the USA in the 1930s (Linnamies, 1956; Siivonen, 1956; Lahti, 1968; Ermala et al., 1989).

The main origin of Eurasian beavers introduced in provinces adjacent to Karelia $(n=1349)$ were the Voronezh Province $(26.5 \%$ of all releases in the study area), Republic of Belarus (20.8\%), Mari El Republic $(12.5 \%)$, Smolensk Province (6.2\%), Bryansk Province (5.3\%), Ryazan Province (3.6\%), Komi Republic 
$(1.5 \%)$, and other regions $(5.6 \%)$. Intraregional translocations of Eurasian beavers have also been conducted (18\%) (Provorov, 1963; Safonov \& Pavlov, 1973; Ivanov, 1975).

In discussing the origin of beavers introduced to the European North, we should remember that many of the areas that served as sources of animals for other regions of Russia had no existing indigenous beaver populations. Beavers in Ryazan and Gorky provinces and Mari El Republic were Voronezh in origin. In the Komi Republic, beavers were released from the Voronezh Province, the Republic of Belarus and the PechoraIlych Nature Reserve. Populations in the Bryansk Province consisted of the few surviving native beavers and animals released from the Voronezh Province and Belarus. Beavers from Belarus also came to the Smolensk Province through natural dispersal (Safonov \& Pavlov, 1973). Considering the quick adaptation of beavers to new habitat conditions, one could assume that newly formed beaver populations would differ significantly from the original ones. We also made such an assertion after observing numerous examples of significant morphological changes that have occurred in various species in new places as soon as after 10 years since their release, i.e. in a relatively short period of time (Schwartz, 1980; Saveljev, 1989, 2003).

Thus, our analysis of the appearance of beavers in the European North of Russia showed that the population of the Eurasian beavers in the study area was formed by animals of different origin. This finding suggests their high genetic diversity and, consequently, higher fitness compared to North American beavers. Comparison of ecological traits of the two species (e.g. diet, building activity) undertaken earlier (Danilov et al., 2007; Danilov \& Fyodorov, 2015b) did not reveal any distinction between species or advantages that allow one species to replace another one.

This study was funded by the Federal Agency for Scientific Organizations (project No. 0221-2014-0006), Russian Foundation for Basic Research (project No. 14-05-00439), and the Russian Academy of Sciences Presidium grant "Living Nature".

\section{References}

Borisov B.P. 2011. [Beaver] // [The state of game resources in the Russian Federation in 2008-2010]. Moscow: Fizicheskaya Kultura. P. 86-90 [in Russian].

Danilov P.I. 1972. [The acclimatization and some ecology peculiarities of North American beavers in Karelia] // Russian Journal of Ecology. Vol.5. P.102-104 [in Russian].

Danilov P.I. 1975. [The state and prospects of North American beaver populations in Karelian ASSR] // Transactions of the Voronezh State Nature Reserve. Vol.21. No.1. P.105-113 [in Russian].

Danilov P.I. \& Fyodorov F.V. 2015a. The history and implications of beaver return to the European North of Russia // Abstracts of 7th International Beaver Symposium. Voronezh. P.21.
Danilov P.I. \& Fyodorov F.V. 2015b. [Comparative characterization of the building activity of North American and Eurasian beavers in northern European Russia] // Russian Journal of Ecology. Vol.46. No.3. P.212-218 [in Russian].

Danilov P.I., Fyodorov F.V., Belkin V.V., Tirronen K.F. \& Panchenko D.V. 2012. Present day situation with North American and Eurasian beavers in the European North of Russia // Abstracts of $6^{\text {th }}$ International Beaver Symposium. Ivaniæ-Grad, Croatia. P.79.

Danilov P.I., Kanshiev V.Ya. \& Fyodorov F.V. 2007. [Beavers of the Russian European North]. Moscow: Nauka. 200 p. [in Russian].

Danilov P., Kanshiev V. \& Fyodorov F. 2011. History of beavers in Eastern Fennoscandia from the Neolithic to the 21 st century // Restoring the Eurasian Beaver. 50 Years of Experience. Pensoft Publishers. P.27-39.

Ermala A., Helminen M. \& Lahti S. 1989. Some aspects of the occurrence, abundance and future of the Finnish beaver population // Suomen Riista. Vol.35. P.108-118.

Ivanov P.D. 1975. [North American beaver in the Karelian Isthmus of Leningrad Province] // Transactions of the Voronezh State Nature Reserve. Vol.21. No.1. P.114120 [in Russian].

Kataev G.D. 2015. Long-term observations over re-introduced beavers Castor fiber orientoeuropaeus on Kola Peninsula, NW Russia // Abstracts of $7^{\text {th }}$ International Beaver Symposium. Voronezh. P.35.

Lahti S. 1968. Majava [Beaver] // Suomen Luonto. No.5. P.110-111.

Lahti S. \& Helminen M. 1969. History of reintroductions and present population status of the beaver in Finland // Suomen Riista. Vol.21. P.67-75.

Lahti S. \& Helminen M. 1980. Suomen majavien levinneisyyden muutokset vuosina 1965-1975 // Suomen Riista. Vol.27. P.70-77.

Linnamies O. 1956. Majavien esiintymisesta ja niiden aihenttamista vahingoista maassamme // Suomen Riista. Vol.10. P.63-86 [in Finnish, with English summary].

Provorov N.V. 1963. [Review of the results of the beaver reintroduction in the North-West of RSFSR] // [Game fauna and game management in the North-West of RSFSR]. Leningrad. P.99-123 [in Russian].

Provorov N.V. 1969. [Present state of beaver colonies in the north-western regions of European part of RSFSR, prospects their growth and possibilities of using in the during nearest five-year period] // Transactions of Voronezh State Nature Reserve. Vol.16. P.75-79 [in Russian].

Safonov V.G. \& Pavlov M.P. 1973. [Beaver] // [Introduction of the game animals and birds in the USSR]. Kirov: Volgo-Vyatskoe knizhnoe izdatelstvo. P.203-294 [in Russian].

Saveljev A.P. 1989. [Comparative biological characteristic of the European and Canadian beavers in the USSR (adaptive changes during acclimatization)]. Dissertatsiya Kandidata Biologicheskikh Nauk [PhD Dissertation in Zoology]. Moscow. 174 p. [in Russian].

Saveljev A.P. 2003. [Biological peculiarities of aboriginal and artificially created beaver populations in Eurasia and their significance for the resource management strategy]. Dissertatsiya Doktora Biologicheskikh Nauk [Dr.Sci Disser- 
tation in Zoology]. Kirov: Russian Research Institute of Game Management and Fur Farming. 201 p. [in Russian]. Schwartz S.S. [Ecological mechanisms of evolution]. Moscow: Nauka. 278 p. [in Russian].

Segal A.N. \& Orlova S.A. 1961. [The beaver appearance in Karelia] // Zoologicheskii Zhurnal. Vol.40. No.10. P.1580-1583 [in Russian].
Semyonov-Tyan-Shansky O.I. 1938. [Re-introduction of beavers in the Lapland State Nature Reserve] // Transactions of Lapland State Nature Reserve. Vol.1. P.177-216 [in Russian].

Siivonen L. 1956. [Suuri nisäkäskirja]. Helsinki. 800 s. [in Finnish]. 